\title{
UM LUGAR NO MUNDO ENTRE O VISÍVEL E O INVISÍVEL: O ATO FOTOGRÁFICO COMO PROPOSTA DE ENSINO PARA O DESPERTAR DE UMA CONSCIÊNCIA ÉTICO-ESTÉTICA DO LUGAR
}

\author{
ONE PLACE IN THE WORLD BETWEEN THE VISIBLE AND THE \\ INVISIBLE: THE PHOTOGRAPHIC ACT AS A TEACHING PROPOSAL \\ FOR THE AWAKENING OF A ETHICAL-AESTHETICS \\ CONSCIOUSNESS OF THE PLACE
}

DOI: $\underline{\text { http://dx.doi.org/10.5965/1984317815022019046 }}$

André Camargo Lopes

Universidade Estadual Paulista

Rede Estadual de Ensino Básico do Estado do Paraná andrecamargolopes1976@gmail.com

\begin{abstract}
RESUMO
Um dos desafios de se ensinar é fazer que aquilo que se ensina dialogue com as subjetividades daqueles que aprendem neste processo. Tornando assim a prática pedagógica algo significativo. O texto corresponde a um relato de experiências educacionais no ensino de Arte desenvolvidas em uma escola pública da rede de ensino do estado do Paraná, na periferia do município de Londrina. Pretende-se debater o processo e os resultados obtidos com alunos do nono ano do ensino fundamental e primeiro e segundo ano do ensino médio. Sendo assim, o texto se volta para os desdobramentos da construção de uma reflexão significativa no processo educacional pautada no desenvolvimento da consciência ético-estética no conjunto de alunos. Como relato de experiência de ensino, o texto se pauta em reflexões e argumentações teóricas e processuais desta ação que resultou na produção de inúmeras imagens fotográficas, assim como centenas de relatos reflexivos de pós-produção apontando as pequenas descobertas críticas do cotidiano. E são nestas descobertas que surgiu no grupo de alunos colocações sobre onde estão inseridos, o espaço naquele momento assumia a condição de lugar.
\end{abstract}

Palavras-chaves: Fotografia, Ensino, Identidade, Espaço.

\begin{abstract}
One of the challenges of teaching is to make what is taught dialogue with the subjectivities of those who learn in this process. Thus making the pedagogical practice something significant. The text corresponds to an account of educational experiences in the teaching of Art developed in a public school of the educational network of the state of Paraná, in the outskirts of the city of Londrina. It is intended to discuss the process and the results obtained with students of the ninth year of elementary school and first and second year of high school. Thus, the text turns to the unfolding of the construction of a significant reflection in the educational process based on the development of ethical-aesthetic awareness in the set of students. As a report of teaching experience, the text is based on theoretical and procedural reflections and arguments of this action that resulted in the production of numerous photographic images, as well as hundreds of post-production reflective reports pointing to the small critical breakthroughs of daily life. And it is in these discoveries that emerged in the group of students placements on where they are inserted, space at that moment assumed the condition of place.
\end{abstract}


Key-words: Photography, Teaching, Identity, Space.

\section{0 espaço que nos cerca: uma proposta de construção ético-estética do olhar}

O conhecimento produzido nas artes visuais é originário de um processo de produção e reflexão estética sobre o mundo no qual estamos inseridos, o que implica em um envolvimento cognitivo da ação perceptível e sensível entre o indivíduo e as formas resultantes deste contato em imagens. A produção destas imagens, principalmente, as que reflitam algum tipo de relação estética com o mundo revela a necessidade de construção e vivências de referenciais imagéticos no processo de formação educacional, viabilizando ao longo do processo um desenvolvimento éticoestético da relação do aluno com o mundo. Pensar o ensino-aprendizagem desta forma potencializa o desenvolvimento cognitivo do olhar, ouvir e sentir do aluno diante do meio (FERRAZ e FUSARI, 2010, p. 76).

Nesta construção perceptiva são inevitáveis as nuances na relação processual do olhar enquanto experiência e conhecimento visual. A respeito desta característica da educação visual, podemos afirmar que cada um vê aquilo que sabe. Logo, permitiu-se que se elaborasse uma proposta de ensino cujo o cotidiano visual fosse tomado por objeto. E a sua exploração realizada como elemento narrativo de uma identidade do espaço.

Tomando a linguagem fotográfica como forma de construção destas narrativas, possibilitou-se organizar a proposta de ensino pautada em um primeiro momento nas seguintes questões de ordem prático-organizacional:

- O que uma fotografia pode dizer sobre aprendizagem?

- O que as imagens fotográficas revelam de nosso olhar para o espaço?

- Como visualizar o processo de ensino e suas estratégias a partir das estratégias de aprendizagem do aluno? 
Desta forma, os códigos visuais foram pensados diretamente relacionados ao conhecimento que o indivíduo constrói das realidades que os rodeiam. Partiu-se do princípio de que a construção do olhar possibilita ao longo da aprendizagem, uma expansão do horizonte perceptivo, viabilizando ao aluno a captação das coisas em suas estruturas, a enxergar além das superfícies cotidianas, “(...) Cada coisa que o olho vê tem uma estrutura de superfície própria e cada tipo de sinal, de granulosidade, de filamento, tem um significado bem claro" (MUNARI; apud FERRAZ e FUSARI, 2010, p. 78).

Neste sentido, procurou-se explorar no exercício fotográfico dos alunos as múltiplas percepções sobre o espaço, assim como estimula-los a compreender que esse se constrói em uma via dupla na qual se relacionam o elemento concreto que se apresenta e as subjetividades que o absorvem. Sobre essa forma de relação com o cotidiano Berger e Luckmann (1985) afirmam que vivemos imersos em uma realidade prática, organizada em sistema de regras e condutas presentes: o imediato. Nessa relação, experiências intersubjetivas contribuem para a construção do cotidiano construído através de diferentes graus de aproximação e distanciamentos espacial e temporal inerentes aos próprios indivíduos. Visto assim, estimular a leitura do espaço através da produção de imagens, viabiliza revelar as bases que estruturam a construção multifacetada da realidade que se expandem através da ação eletiva, imposta pela subjetividade.

A realidade da vida cotidiana aparece já objetivada, isto é, constituída por uma ordem de objetos que foram designados como objetos antes de minha entrada na cena. A linguagem usada na vida cotidiana forneceme continuamente as necessárias objetivações e determina a ordem em que estas adquirem sentido e na qual a vida cotidiana ganha significado para mim. Vivo num lugar que é geograficamente determinado; uso instrumentos, desde os abridores de latas até os automóveis de esporte, que têm sua designação no vocabulário técnico da minha sociedade; (...). Desta maneira a linguagem marca as coordenadas de minha vida na sociedade e enche esta vida de objetos dotados de significação.

(BERGER \& LUCKMANN, 1985, pps.38-39) 
Os passeios fotográficos surgiram como forma de construção de uma identidade crítica e afirmativa do aluno em relação ao bairro habitado, assim como do colégio e de seu entorno. O bairro assim como a escola são absorvidos pela rotina cotidiana, o que valida as experiências de exploração destes. Uma vez refletidos, mediados pelas câmeras fotográficas, passam a ser internalizados, revelando a subjetividade que os envolve, ou melhor os constrói. Desta forma A proposta de ensino se estruturou, na prática em uma pergunta simples: Qual lugar posso chamar de meu?

É uma indagação que remete a dois problemas centrais em Educação: a relação do indivíduo com o espaço, e, a sua construção identitária.

Como experiência pedagógica, os três momentos de experiência fotográfica (2010, 2017 e 2018) serão apresentados dentro dos debates suscitados expondo nestes a produção e reflexão sobre as imagens resultantes deste espaço social, revelando variações e permanências interpretativas dos alunos e os problemas pontuais específicos do período do registro ${ }^{1}$. Desta forma, ao longo do texto o processo e resultados de uma proposta de ensino com alunos da educação básica (ensino fundamental anos finais e ensino médio) seja por meio das fotografias produzidas, seja por meio de seus relatos irão se revelando e buscas compositivas e em reflexões éticoestéticas.

\footnotetext{
1 Essa experiência de ensino, foi iniciada em 2010, no Colégio Estadual Professora Roseli Piotto Roehrig, localizado no conjunto Habitacional José Giordano, na região norte do município de Londrina (PR). Sobre os aspectos socioeconômicos da região atendida pelo colégio. Trata-se de uma região habitacional densa, com favelas, e bairros de famílias empobrecidas de baixa instrução escolar. A sujeira do espaço, acaba se tornando sua principal característica, demandando propostas educacionais que fizessem com que os alunos moradores desta região passassem a refletir sobre o impacto da ação humana e as necessidades de políticas públicas no espaço. Com, isso, comecei a desenvolver proposta-aulas cujos os elementos estéticos estavam atravessados por compreensão crítica do meio. A primeira experiência foi em 2010 com turmas de nono ano do ensino fundamental, entretanto, devido as dificuldades na época de se conseguir câmeras fotográficas para todos os alunos, ou em número satisfatório para que se conseguisse realizar um bom trabalho, retornei a experiência somente em 2017, quando o perfil das turmas que ministrava me permitiu explorar o uso destes aparelhos. Percebe-se no próprio hiato entre as experiências, questões relevantes à formação socioeconômica dos alunos e a comunidade escolar, assim como a familiaridade com a visualidade e a sua produção. Logo, os relatos de experiências presentes neste texto, remetem aos passeios fotográficos de 2010, 2017 e 2018, com alunos de primeiro e segundo ano do ensino médio. Todos permeados pela mesma proposta metodológica, como variações pertinentes ao perfil da turma, mas gerado a partir dos problemas e questionamentos já apresentados no texto. Neste período entre 2010 e 2017, realizei experiências menores com alunos das mais variadas turmas e séries, possibilitando o amadurecimento da proposta pedagógica com que trabalhei em 2017 e 2018.
} 


\section{A criação como processo: Para onde apontam as câmeras?}

As questões dadas até aqui podem ser compreendidas a partir das diversas subjetivações que envolvem a experiência de aprendizagem em uma proposta de ensino. Quando pensamos a relação do indivíduo com o espaço e o resultado desta como imagem, é compreensível que tenha na subjetividade do olhar e suas escolhas, uma maneira de nos individualizarmos no mundo. Pedagogicamente, no ensino de Arte, estimula-se a contemplação-reflexiva, e com isso, o desenvolvimento das sensibilidades perceptivas. Logo, ao descobrir o olhar, o indivíduo passa a perceber-se como um construtor de narrativas, capaz de dotar de significações o meio que o envolve. Com isso, tende a elencar, selecionar, e individualizar as coisas a partir de seus critérios investigativos. Com isso, pode-se afirmar que a imagem resultante deste contato é algo único, decorrente de um processo de internalização, visto que o indivíduo se relaciona com o mundo sensível a partir de seu mundo interno.

O olhar como ferramenta de aprendizagem se consolida como uma ação consciente e seletiva, repleto de pré-situações, de reminiscências que estabelecem um elo significativo entre o indivíduo em ação e o estimulo exterior.

A fotografia neste processo, como forma de captação e criação visual no ensino de Arte possibilita ao aluno uma abertura a novos códigos visuais, modificando na relação deste com o meio que o envolve em uma ação de observação e escolha. Esta relação é possibilitada graças a condição processual do exercício fotográfico que requer daquele que fotografa dois estágios de entendimento: o domínio técnico do material que se manuseia (aparelho celular, câmera fotográfica digital, MP5) e o estudos empíricos do próprio objeto a ser fotografado, revelando nesta processualidade elementos próprios da condição estética da imagem (cor, suporte, textura, luminosidade, forma e composição). Neste sentido, a ação que constitui a imagem fotográfica se revela como uma ação mediadora em processo e dotada de significações. 
Visto assim, Dubois (2009, p.59) coloca que a natureza da imagem fotográfica se dá a partir do pressuposto de que "a fotografia (...) não é apenas uma imagem produzida por um ato, é também, antes de qualquer outra coisa um verdadeiro ato icônico "em si", é consubstancialmente uma imagem ato". Sendo assim, a linguagem fotográfica se consolida como um modo constitutivo tanto em sua produção como em sua fruição ou difusão. Essa ideia é complementada por Sontag (2004), visto que a mesma afirma que a construção da imagem fotográfica e suas muitas significações, embora seja resultado da captação da realidade pela câmera fotográfica, estas são interpretações de mundo tanto quanto a pintura ou o desenho. Sendo assim, a imagem fotográfica se consolida em uma complexa relação entre a intencionalidade e a sua atestação indiciária do referente.

Na prática pedagógica, a complexidade desta condição da imagem fotográfica é percebida nas imprecisões dos alunos quando colocados a refletir sobre o (e no) processo fotográfico e a sua ação de escolha e composição na constituição de uma relação entre referente e imagem. É a partir da problematização desta relação produtor/fruidor entre os alunos que se pretende discutir elementos relacionados à prática de ensino e aprendizagem em Arte. Ou seja, uma proposta de aprendizagem focada no conjunto de experiências perceptivas vividas pelos alunos dentro da ação fotográfica. Tal proposta enfatiza a correlação entre o aluno (agente perceptivo) e o espaço (objeto perceptivo), tal como proposto por Merleau-Ponty em sua definição de corpo operante "(...) o ser se vê vidente, toca-se tateante, confunde-se com as coisas do mundo e, tomado no meio delas, é captado na sua contextura" (MERLEAU-PONTY apud ARANHA, 2008, p. 24). Neste sentido, o fotografar tornou-se uma abertura capilarizada entre o aluno e o seu espaço cultural, em um olhar estético consciente sobre si no espaço.

Foi notório nos três momentos de experiências, a presença nos relatos de muitos alunos ao refletirem sobre os espaços do bairro na possibilidade de se desenvolver um trabalho de construção de uma narrativa deste, uma relação 


\section{conflituosa entre o jovem e o espaço, muitas vezes em condição de estranhamento e} familiarização, como pode-se ver nos relatos abaixo:

Tabela 1

Questionário aplicado aos alunos dos primeiros anos do ensino médio da turmas A e B - novembro de 2018.

\begin{tabular}{|c|c|}
\hline Questionamentos & Respostas \\
\hline $\begin{array}{l}\text { As ruas de meu } \\
\text { bairro têm... }\end{array}$ & $\begin{array}{l}\text { "Crianças brincando nas ruas". } \\
\text { "Nomes de café." } \\
\text { "As casas que foram pintadas de forma que juntas formam uma sequência. E por sinal } \\
\text { são fantásticas". } \\
\text { "Pedras, barro, traficantes, drogados, pinguços e bêbados." }\end{array}$ \\
\hline $\begin{array}{l}\text { No meu bairro as } \\
\text { ruas é para... }\end{array}$ & $\begin{array}{l}\text { "Vender drogas, tiroteio, jogar lixo e fazer caminhada". } \\
\text { "Traficar, brincar, sofrer acidentes, sua casa ser roubada e jogarem lixo". }\end{array}$ \\
\hline $\begin{array}{l}\text { Para chegar em } \\
\text { meu bairro você } \\
\text { precisa de... }\end{array}$ & $\begin{array}{l}\text { "É preciso andar muito." } \\
\text { "Coragem. Só tem uma rua para entrar e sair, uma estradinha de terra para os } \\
\text { pedestres". } \\
\text { Dar uma caminhadinha. Mas é bem rápido, não demora muito." }\end{array}$ \\
\hline $\begin{array}{l}\text { O que falta em meu } \\
\text { bairro é... }\end{array}$ & $\begin{array}{l}\text { "Vizinhos que cuidem de suas vidas". } \\
\text { "No bairro é preciso daquelas lixeiras porque os cachorros carregam os lixos quando está } \\
\text { no chão e o povo tem que parar de jogar lixo na rua". } \\
\text { "Um asfalto porque é de terra e tem muito buraco. E de policiais porque tem muito Zé } \\
\text { Droguinha". }\end{array}$ \\
\hline $\begin{array}{l}\text { Algumas pessoas } \\
\text { são inesquecíveis } \\
\text { em meu bairro... }\end{array}$ & $\begin{array}{l}\text { "Minha tia que mora ao lado. Todo mundo a conhece". } \\
\text { "Meus amigos que jogaram bola comigo". } \\
\text { "Porque são agitadas e adoram cuidar da vida dos outros". } \\
\text { "A Celinha. Fofoqueira e gente boa. Não entende nada de tecnologia. A vizinha que fica } \\
\text { gritando com s filhos, que dá para escutar há vários quarteirões de distância e as } \\
\text { vizinhas gostosas". } \\
\text { "As vizinhas fofoqueiras, os carinhas que vendem drogas e as crianças que vem gritando } \\
\text { do colégio". }\end{array}$ \\
\hline $\begin{array}{l}\text { O que me encanta } \\
\text { em meu bairro é... }\end{array}$ & $\begin{array}{l}\text { "Todo o final de semana as crianças brincando no parque que está todo quebrado". } \\
\text { "As cores das casas, a praça e o modo como as casas são construídas". } \\
\text { "O que me encanta né que no campo há vários cavalos, cheio de árvores, flores, gramas } \\
\text { com campinho". }\end{array}$ \\
\hline $\begin{array}{l}\text { Há coisas que } \\
\text { mudaria em meu } \\
\text { bairro... }\end{array}$ & $\begin{array}{l}\text { "Tais como: lixo, jogado nas ruas, a irresponsabilidade em deixar animais soltos nas } \\
\text { mesmas". } \\
\text { "Mudaria as questões de segurança" } \\
\text { "Mais policiais nas ruas, mais profissionais de saúde e melhoria nas ruas". } \\
\text { "As ruas com buracos e terrenos baldios". }\end{array}$ \\
\hline $\begin{array}{l}\text { O que faz ser meu o } \\
\text { bairro em que vivo... }\end{array}$ & $\begin{array}{l}\text { "As pessoas usarem drogas nas esquinas". } \\
\text { "Nossa casa, o nosso ipê amarelo. Tudo que vivenciamos aqui". } \\
\text { "É porque cresci lá, e tenho muitos amizades. É o lugar em que meu pai comprou nossa } \\
\text { casa, e essa casa vai ser minha no futuro". }\end{array}$ \\
\hline
\end{tabular}




\begin{tabular}{l|l}
\hline $\begin{array}{l}\text { Algo me assusta em } \\
\text { meu bairro... }\end{array}$ & $\begin{array}{l}\text { "A vizinha da minha tia, ela é assustadora". } \\
\text { "A poluição do meio ambiente. Nas praças, quintais, ruas, campos etc." } \\
\text { O que me assusta é o excesso de violência". }\end{array}$ \\
\hline $\begin{array}{l}\text { Existem cheiros } \\
\text { peculiares em meu } \\
\text { bairro... }\end{array}$ & $\begin{array}{l}\text { "Há vários cheiros diferentes, mas todos ao mesmo tempo. Cheiro de cavalo, drogas e } \\
\text { esgoto". } \\
\text { "Na maioria são odores desagradáveis causados pela população. Exe.: lixo nas ruas". } \\
\text { "Cheiro de chiqueiro de porcos". }\end{array}$ \\
\hline $\begin{array}{l}\text { Há co is a s que } \\
\text { fotografaria em meu } \\
\text { bairro... }\end{array}$ & $\begin{array}{l}\text { "Fotografaria as árvores, os cachorros e os pássaros". } \\
\text { "A reciclagem que pegou fogo". } \\
\text { "Eu fotografei o pé de coco" no meu bairro". }\end{array}$ \\
\hline $\begin{array}{l}\text { Essa é uma das } \\
\text { muitas histórias que } \\
\text { te n h o de m e u } \\
\text { bairro... }\end{array}$ & $\begin{array}{l}\text { "Que uma vez o cara estava na casa do meu primo quando os caras passaram atirando." } \\
\text { "Todo ano havia festa para as casanças. Havia festa junina também." } \\
\text { "Parece filme dos velozes e furiosos. Muita corrida de carro e perseguição. Policiais } \\
\text { versus bandidos". }\end{array}$ \\
\hline $\begin{array}{l}\text { Quais marcas fiz na } \\
\text { rua em que moro... }\end{array}$ & $\begin{array}{l}\text { "Por minha família ser muito briguenta, por meus familiares". } \\
\text { "Enfeitei a guarita do meu vizinho com garrafas". } \\
\text { "Marcas de Jogos". } \\
\text { "Festas, atentei meus vizinhos com som". }\end{array}$ \\
\hline
\end{tabular}

Essa atividade foram aplicadas como forma de problematização da exploração fotográfica pelas ruas dos bairros. Tinha como objetivo verificar a leitura que esses jovens faziam do espaço. Metodologicamente, os alunos deveriam complementar as frases com suas leituras específicas do espaço, como era uma atividade que propunha a eles uma dinâmica em grupo, os papeis não foram nomeados pois cada aluno pegou aleatoriamente dois questionamentos, para refletirem sobre o tema e depois retornarem para serem sorteados, lidos e debatidos pelo grupo. Participaram desta experiência aproximadamente 60 alunos com idades entre 15 e 18 anos.

A amostragem acima, apresenta um resumo do que foram os temas predominantes nas respostas dos alunos: o lixo espalhado pelo espaço, o tráfico de drogas e a insegurança. Assim como, contraditoriamente, os locais de brincadeiras, os personagens e a paisagem seletiva.

E foi sobre esse confronto entre o cotidiano e as possibilidades de explorá-lo que residiu toda a experiência fotográfica. $O$ olhar destes alunos se defrontou com um estranho processo de seleção, de alteração de sua rotina visual, descaracterizando 


\section{EDUCAÇÃO, ARTE'S E INCLUSÃO}

desta, a homogeneização que envolve a todos na construção do cotidiano, desvelando para este, seja de forma positiva o negativa, elementos estéticos e humanos que compõem a paisagem social do bairro. O olhar se tornou ferramenta de ressignificação do espaço, permitindo que através da fotografia, que cada pessoa envolvida, manifestasse determinada sensibilidade singular e ávida (SONTAG, 2004, p. 106). Ou seja, uma reconstrução, deste a partir de seus lugares íntimos, selecionados pelos próprios alunos.

A aprendizagem que envolve a construção e a descoberta da imagem e seu discurso, possibilita a formação de um olhar consciente sobre os lugares de vivência, como visto na dinâmica apresentada na tabela 1. Lugares afetivos ou não, capazes de se tornarem significativos para estes, e que convertidos em imagem assumem uma nova conotação simbólica, como podemos ver nas imagens abaixo, realizadas na área interna do colégio:

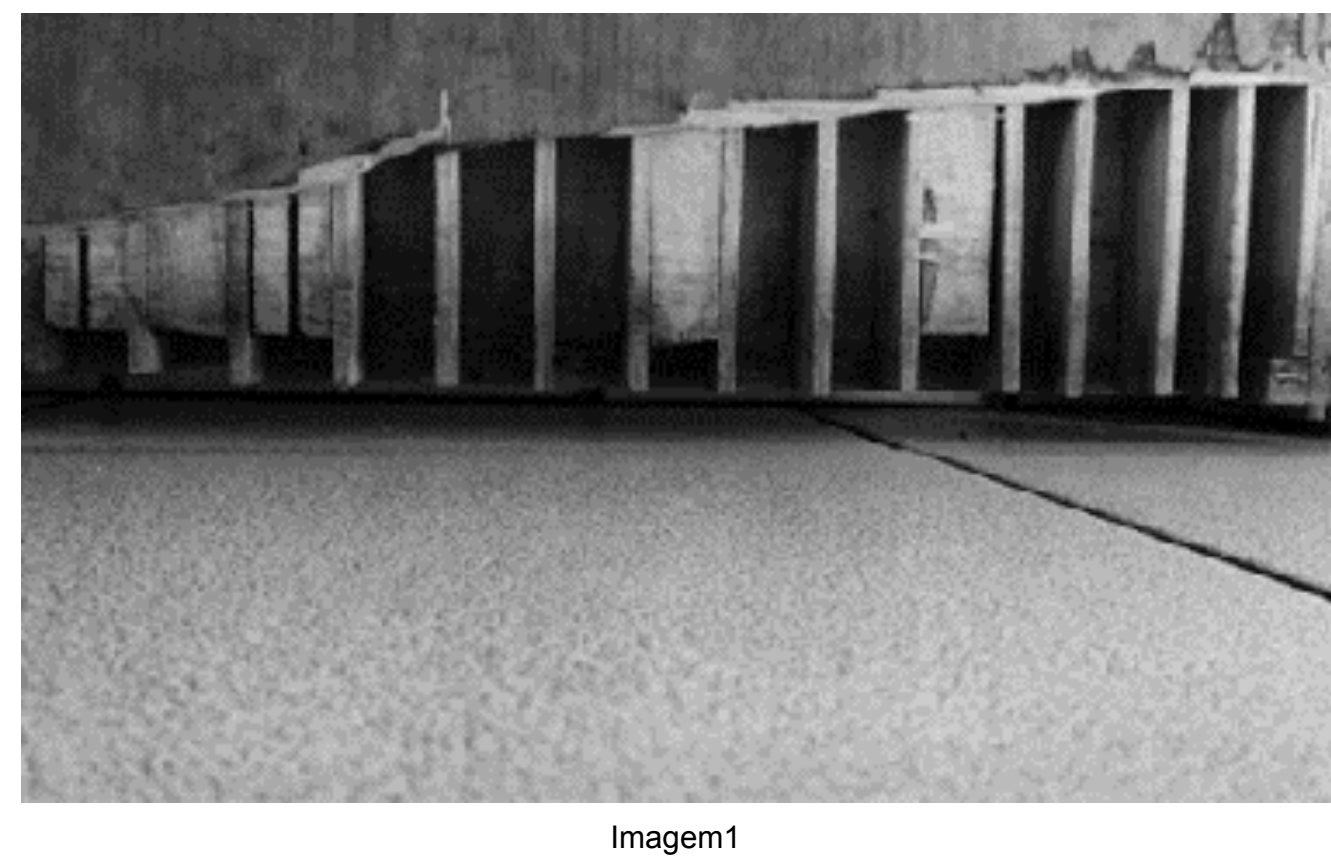

Autor: M. M. (16 anos)², Explorações pela escola, 2018. Fotografia digital com dispositivo móvel.

2 Por serem alunos com idades entre 15 e 18 anos, optamos por especifica-los pelas iniciais dos nomes e idade entre parênteses. 
No ensaio exemplificado, M. M. (16 anos), deliberadamente explora os "cantos" do espaço escolar. As bicicletas, janela quebrada, os ralos, a descascado da porta. Tudo é tema para seus registros. Seu olhar se mantem em planos fechados, como se explorasse micro-espaços.

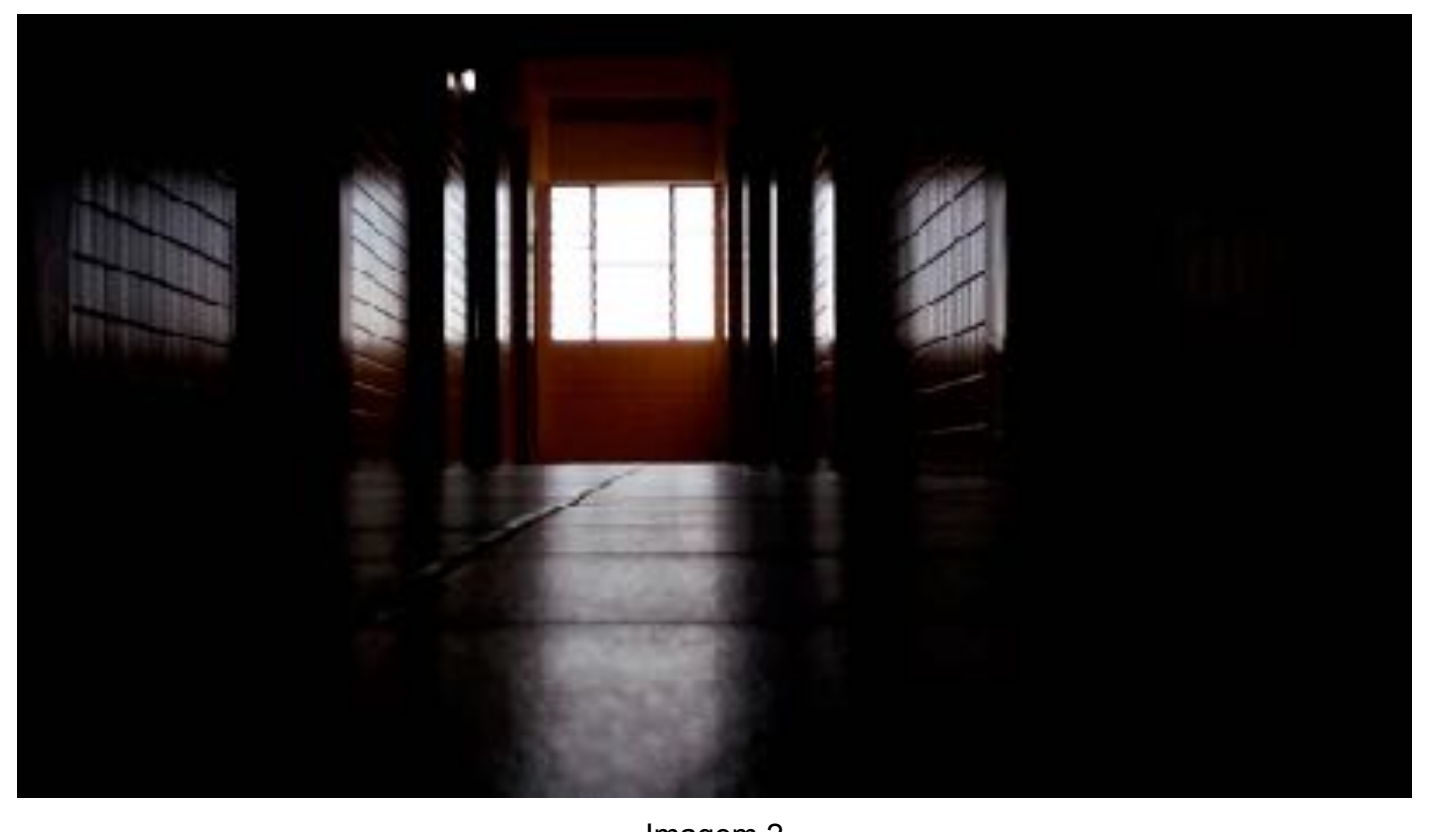

Imagem 2

W. S. (16 anos), Explorações pela escola, 2018. Fotografia digital com dispositivo móvel.

Diferentemente de M. M (16 anos), a aluna W. S. (16 anos), explorou na mesma experiência, registros de planos abertos, explorando a geometria do lugar. Em algumas de suas fotografias, afirma querer explorar a luz que entrava nas salas e nos corredores.

"O espaço que escolhi para fotografar, contém portas marrons, algumas lâmpadas uma parede com detalhes quadriculados amarelos, alguns pilares que fazem as divisões das salas. Uma janela bem ao fundo do corredor, que traz luminosidade para todo o corredor, tem paredes claras. Esse local foi escolhido porque através da luz da janela refletida no chão, causa um contraste interessante. $O$ foco da minha fotografia foi a luz da janela, tirando a foto de baixo para cima, numa determinada distância fez com que o espaço ficasse escuro com foco de luz somente na janela o que fez a foto ficar muito interessante". W.S. (16 anos). 
Os espaços internos do colégio foram, nas experiências o primeiro momento de reflexão sobre as construções visuais possíveis. Experiências de escolhas, nas quais os alunos se colocavam em situações de produtores-reflexivos, visto que a imagem não era o ponto final do processo, mas sim a reflexão e o debate sobre o espaço.

\section{Extrapolando os muros do colégio: Os passeios fotográficos}

Após as experiências desenvolvidas dentro do espaço escolar, explorando possibilidades descritivas, sejam elas desenhos ou escrita, vieram os passeios fotográficos, que pretendiam expandir o olhar do aluno frente sua capacidade perceptiva do espaço reconstruindo o olhar apontado na tabela 1.

Os passeios fotográficos consistiam em caminhadas no entorno da escola, pelos bairros que a cercam, durante o horário de aulas ${ }^{3}$. Tínhamos como única proposta de observação em campo de que olhassem para os espaços, e os entendessem como lugares, pontos vivência, de estudo e trânsito, e que constituíssem este conjunto de possibilidades de imagens presentes em seu cotidiano. De forma concreta foi proposto a estes que passassem a relacionar com o espaço cotidiano como parte significativa de sua existência, ou mais, que permitissem através de uma reorientação, ou um olhar construtivo, uma reconstrução de sua própria consciência de espaço.

3 Em 2010, explorei por oito aulas esses passeios, enquanto que em 2017, foram dedicadas quatro aulas, com explorações em contraturno. Já em 2018, foram 4 investidas e as explorações em contraturno. Os horários de aulas nestes dias, tiveram que ser arranjados pela equipe pedagógica, pois em média eram disponibilizadas duas horas relógio para que caminhasse com os alunos nas imediações. 


\section{EDUCAÇÃO, ARTE'S E INCLUSÃO}

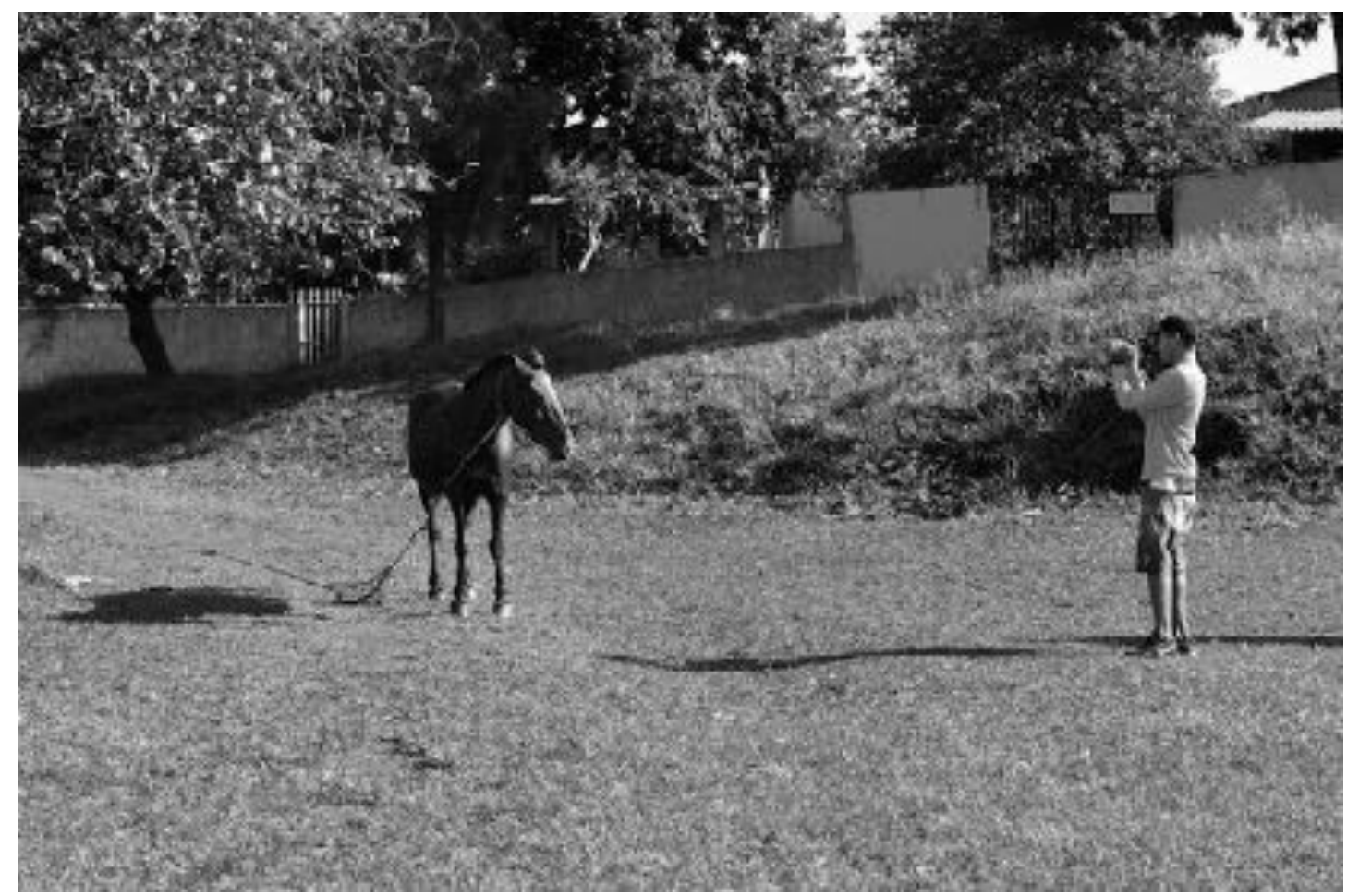

Imagem 3

André Camargo Lopes, passeio fotográfico pelo Conjunto Parigot de Souza, 20 de novembro de 2018.

Tal proposta remete ao que Canton (2009) classifica como um jogo epistemológico que coloca em conflito posicionamentos distintos na relação do sujeito com o todo, a sua condição identitária, ou seja, a conversão de uma leitura genérica (espaço) para algo familiarizado, particular, algo que traz em si a construção de uma referência local.

A aventura fotográfica neste processo de aprendizagem ético-estética colocou os alunos em uma ação constante de descobertas visuais, tácteis, sonoras e olfativas. Trazendo à epiderme cotidiana, elementos até então fugidios no próprio cotidiano do bairro.

O que ao longo do processo de produção fotográfica a conversão do espaço em lugares, e destes em imagens, possibilitaram aos alunos, em seus muitos olhares, um novo encontro com o eu e com o outro, que neste desbravar fotográfico, é o próprio 
bairro, em cores e vida. É o saber-pensar proposto por Aranha (2008) que se consolida neste processo de reflexão e criação fotográfica.

A fotografia como fora dita anteriormente, potencializa a catalisação em sua condição de mediadora entre o olhar e o espaço, uma ação fenomênica de conhecimento de mundo, que permite ao aluno se construir esteticamente a partir de sua aproximação com os elementos componentes no espaço passiveis de serem convertidos em códigos visuais. Para Aranha, o olhar é algo orgânico, que requer deslocamentos por estar diretamente integrado a um corpo, "(...) no momento em que meu olhar se move, meu corpo se move, me aproximo do mundo por essas movimentações e vejo que o movimento é parte da visão" (ARANHA, 2008, p. 20). É na relação paradoxal entre o ver e o ser visto que reside o reconhecimento de si naquilo que se vê, estabelece assim, uma troca em um despertar de ecos de visualidades. Esta perspectiva construtiva do olhar remete a necessidade de sair de sala de aula, expandir o cotidiano relacional do aluno para além dos muros da escola, reconstruir os seus passos cotidianos pelo bairro que pertencem.

Nesta experiência, explorou-se as possibilidades de registro da paisagem que envolvia o colégio. Partindo da premissa exposta pelos próprios alunos da ação direta ou indireta que a composição física e humana deste espaço, interfere em suas rotinas, representações e organização do modo de vida. 


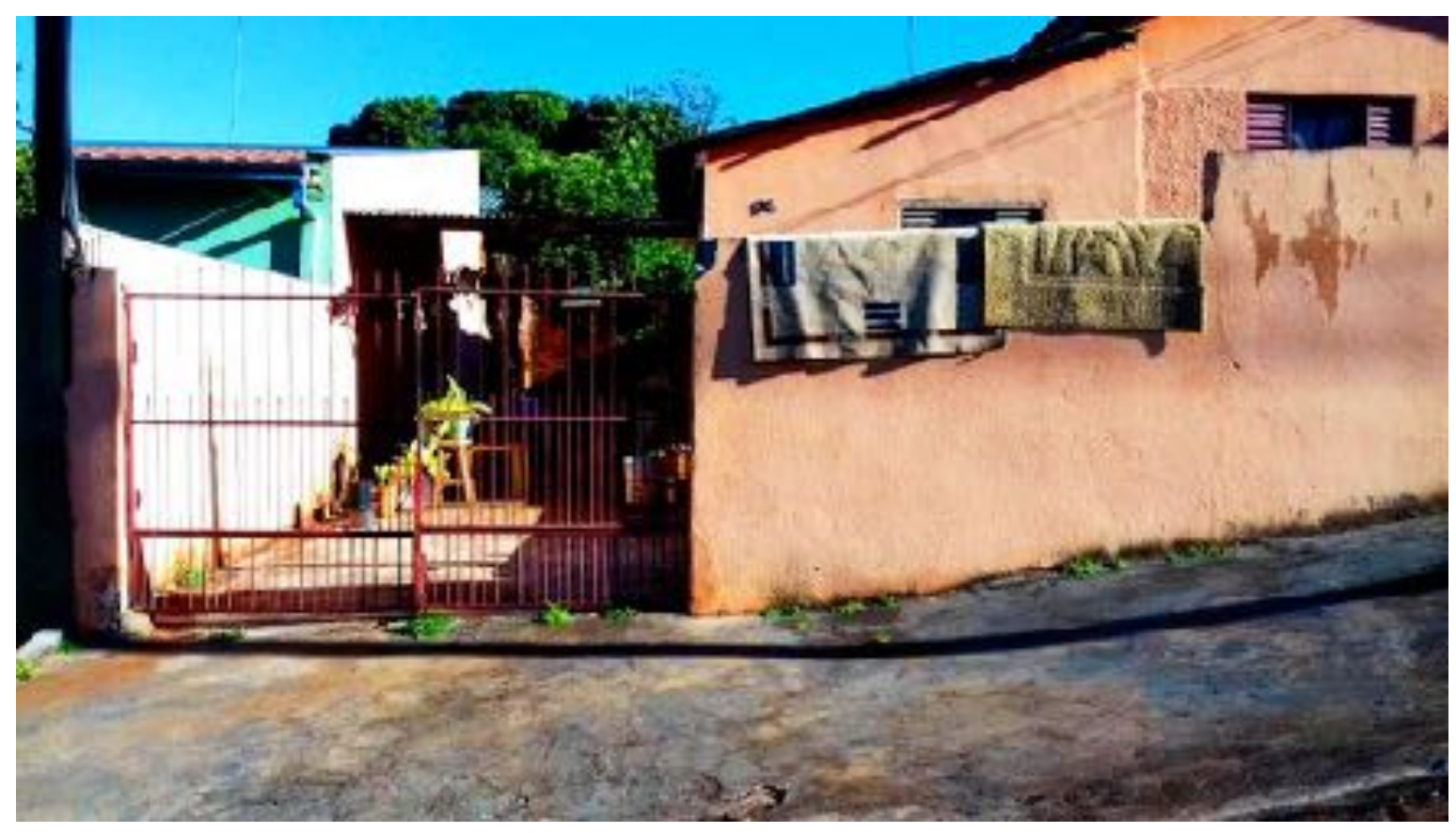

Imagem 4

E. V. (15 anos), Secando tapetes, Conjunto Parigot de Souza II, 2018.

Desses encontros entre os alunos e o espaço surgiram inúmeras de imagens que procuraram explorar e narrar o bairro em suas particularidades. Algumas lentes voltavam-se para arquitetura. Outras, para os detalhes, os arranjos que a compõe. E outros simplesmente se envolviam com toda forma de manifestação de vida da localidade.

\section{Toda experiência educacional tem uma trajetória: desafio de se pensar a prática de ensino como vivência}

Toda experiência educacional tem seu começo. A primeira incursão fotográfica foi realizada em 2010, com turmas de alunos do nono ano do Ensino Fundamental. Procurava na experiência de ensino estimula-los e pensarem a Arte como forma de autoconhecimento. As atividades transitavam entre a escassez de material, e o desinteresse dos alunos pelo componente curricular. 


\section{EDUCAÇÃO, ARTE'S E INCLUSÃO}

Inicialmente, foi proposto que refletissem sobre a linguagem fotográfica. Neste sentido, na proposta de 2010, tinha-se como problema inicial os elementos compositivos de uma fotografia. A medida que exploravam a linguagem, permitiam que fossem inseridos temas como elementos problematizantes. Inicialmente o retrato e a paisagem escolar. Foi uma etapa na qual os alunos exploravam a construção e a descoberta da imagem e seu discurso, possibilitando a formação de um olhar consciente sobre os lugares de vivência. Neste caso específico, a própria escola, que surgia como personagem central nas diversas narrativas fotográficas apresentadas.

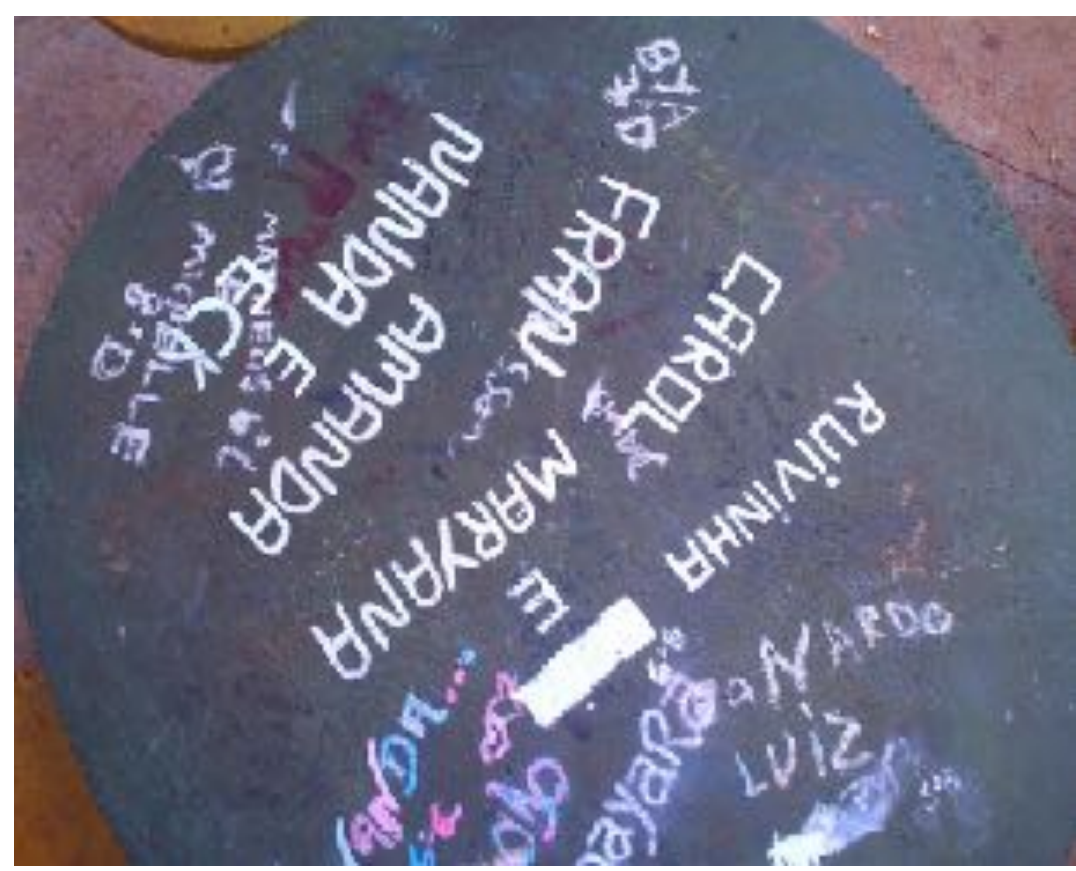

Imagem 5

A.A. (16 anos) Praça de Recreação do Colégio Est. Prof. Roseli Piotto Roehrig Autora: Alisson Augusto, $2010^{4}$

Com os resultados desta primeira experiência. Outra indagações foram feitas:

\footnotetext{
4 As marcas produzidas no espaço escolar pelos próprios alunos, refletem nesta composição em ângulo zenital, uma ação metalinguística a partir da leitura realizada pelo aluno quando da valorização do grafismo na mesa. São marcas identitárias familiarizadas pelo próprio cotidiano de relações do colégio. Códigos visuais que são ilhados na fotografia, isolados de seu contexto e sujeitos a interpretações que extrapolam as interpretações iniciais de seu autor.
} 
- Como esses jovens viam o espaço que os envolve?

- Qual seria o bairro retratado por eles?

Não havia câmeras fotográficas para todos, a atividade foi realizada com alguns poucos aparelhos (três câmeras digitais que havia trazido, um MP5 de uma aluna e dois aparelhos celulares), o que fez com que a atividade se desenvolvesse em grandes grupos.

Nesta experiência foram realizadas oito incursões fotográficas no bairro. Todas de espaço de cinquenta minutos, o que obrigava que a rota de atividade fosse definida de forma objetiva e com muita antecedência.

Destas incursões resultaram um total de 1055 fotografias realizadas pelos 87 alunos envolvidos. Tudo se revelou como novidade, os espaços, suas texturas, a luz e os personagens que o povoavam. Foi uma espécie de descoberta coletiva, no qual todos descobriram algo: os alunos passavam a pensar o espaço de trânsito e moradia como algo dotado de sentido, os moradores se permitiam participar destas imagens, assumindo uma relação participativa na construção destas narrativas. Entretanto, as pesquisa voltavam-se sempre para o elemento plástico, como proposta buscava-se essa plasticidade do cotidiano.

Esta definição aplicada dentro da proposta de ensino-aprendizagem possibilitou ao aluno uma reflexão mais complexa sobre o próprio ato criador (no caso desta experiência plástica: o ato fotográfico), podendo pensá-lo dentro de sua condição narrativa e plástica. 


\section{EDUCAÇÃO, ARTE'S E INCLUSÃO}

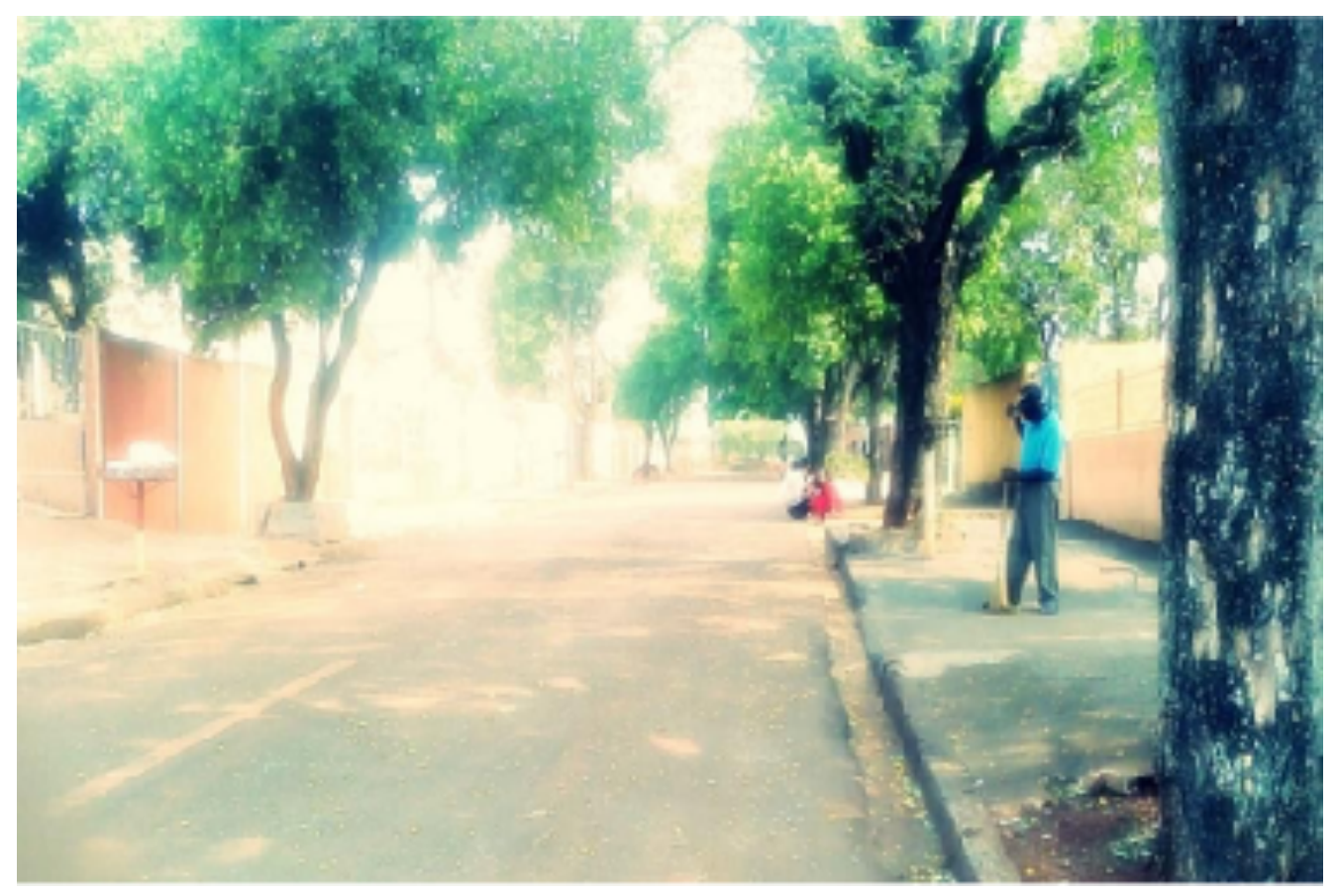

Imagem 6

L. S. (15 anos), Morador varrendo a frente de sua residência no Conjunto Chefe Newton, 2010.

Massas cromáticas e texturas diversas foram os elementos de maior destaque nas composições resultantes. As fotografias em sua grande maioria foram registradas em ângulo e planos fechados, em que o enquadramento favoreceu aos trabalhos fotográficos a exploração mais precisa das texturas, assim como a valorização expressiva, das variações cromáticas sobre os corpos como podemos ver na imagem a seguir. 


\section{EDUCAÇÃO, ARTE'S E INCLUSÃO}

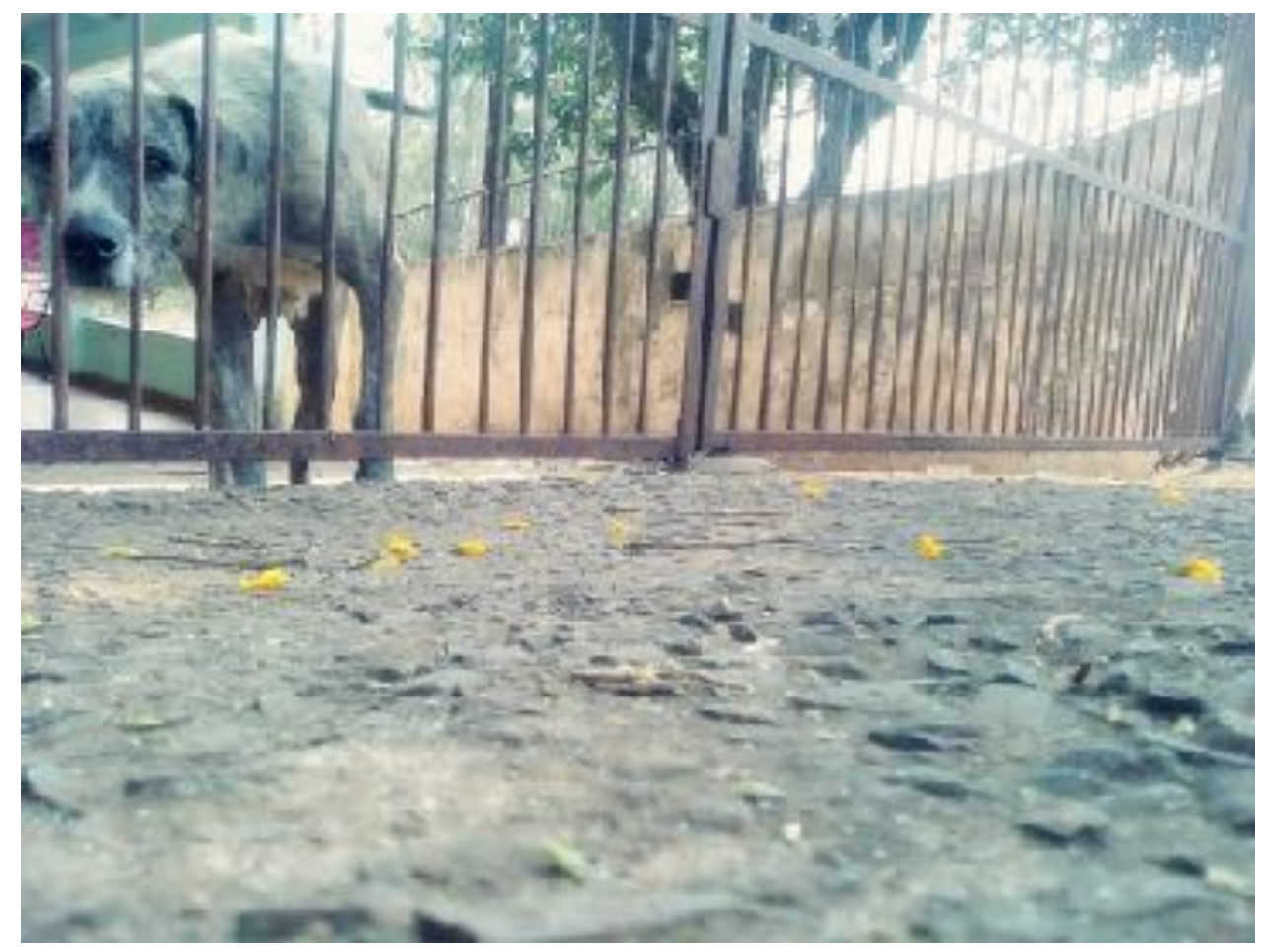

Imagem 7

L. S. (15 anos). Cachorro, Conjunto Parigot de Souza II, 2010

Nota-se nas imagens produzidas por L. S. (15 anos) que a construção da planificação fotográfica se dá de forma consciente a partir de referentes visuais trabalhados em sala de aula5. Sua preocupação compositiva em ambas as imagens é construir uma narrativa sobre a ação e os agentes registrados. O critério utilizado para a delimitação compositiva destas imagens, constitui-se em suas funções narrativas, sendo assim, a definição dos planos visuais definem uma intencionalidade visual, ou seja, a planificação visual possibilitou uma descrição hierárquica dos elementos compositivos valorizando no discurso imagético o seu sentido narrativo.

Este entendimento cria duas projeções visuais distintas, enquanto que na imagem 6 a diagonal da rua recortada em um plano geral permite uma leitura da ação dos

\footnotetext{
5 Durante as aulas expositivas, e os exercícios experimentais de composição fotográfica, trabalhou-se com questões técnicas de composição explorando texturas, planos e luminosidade. Fotógrafos como José Bassit e Luiz Braga, serviram de referência de trabalhos exploratórios.
} 
agentes retratados, na imagem 7, o cachorro é trazido para fora da ação compositiva, coloca-o em interação com o espectador. Esta intencionalidade narrativa da aluna se faz presente em sua fala sobre os estudos fotográficos que realizou ao longo das experiências desenvolvidas nas aulas extra-sala:

A eu o que era e não era, isso arvore eu não percebia os detalhes dela. Eu não ligava o que as pessoas fazia, eu só sentia o vento mais não via o que ele pode faze e fazia, eu via o meu bairro como um lugar que eu vivo não aonde eu moro. (...) Agora eu posso ver os detalhes das coisas até os mínimos espaços que eu não via, os movimentos que o vento faz nas arvores, como é interessante ver o jeito de algumas pessoas varrendo o formato das coisas, a textura do chão, as sombras, e como a gente pode ficar no meio da luz. L. S. (15 anos $)^{6}$

Percebe-se neste relato o início de uma pesquisa da visualidade nas imagens fotográficas produzidas pela aluna. Há mais que um olhar inocente sobre o espaço, há a construção de uma narrativa, uma intencionalidade interpretativa dos referentes visuais que a envolvem, há uma ação perspectiva do aluno/fotógrafo, um posicionamento. Uma leitura que se estrutura em significados e situações que não são diretamente próprios daquilo que está sendo fotografado, e daqueles que estão sendo fotografados, mas se refere à própria inserção do aluno/fotógrafo no espaço referente, e o seu processo de seleção e recorte do espaço analisado.

Acerca desta possibilidade, tomados como exemplos os dois estudos fotográficos de L. S. (15 anos). Sua preocupação de captar massas densas com grandes áreas de sombras revelou-se como o seu principal objetivo estético (assim como de outros alunos). Neste exercício fotográfico, em que a ação dos retratados é absorvida pela luz matinal que penetra as copas das árvores, Letícia procurou registrar as áreas diluídas pela luz em massas sólidas nítidas no plano compositivo direito.

Neste sentido, percebe-se que além de uma construção reflexiva sobre o referente visual (DUBOIS, 2009). Sendo assim, a proposta de ensino neste estágio inicial já possibilitava ao aluno em sua ação compositiva se deparar com uma reflexão

\footnotetext{
${ }^{6}$ Procurei manter a escrita original da aluna.
} 
constante sobre os elementos próprios da natureza da imagem. Nesta experiência a descoberta da imagem e sua estrutura, possibilitou ao aluno um jogo de signos e significados entre o referente e o resultante visual, estimulando-os a debaterem e a refletirem sobre suas produções um raciocínio diferenciador entre imagem e realidade (JOLY, 2008). A ação fotográfica como prática criadora, possibilitou com que criassem suas próprias mensagens visuais (seja em sua leitura ou criação, como é o caso deste trabalho), o que dentro do quadro de análise de Joly, esta determina-se por um relacionamento de associação e diferenciação entre os signos icônicos e os signos plásticos. Como visto na tabela abaixo:

Tabela 2

Signos visuais de uma imagem

\section{Signos icônicos}

\section{Signos plásticos}

- Elementos análogos ao da realidade referente;

- Figuras que contribuem de forma decisiva para a

- Cor; compreensão narrativa da imagem;

- Textura;

- Composição;

- Formas;

A imagem surge assim, como um resultante relacional mantem-se presa à realidade por sua natureza indiciária, mas ao mesmo tempo se distancia desta por sua condição plástica. Esta condição paradoxal da imagem se faz presente nas falas dos alunos/fotógrafos quando indagados sobre a relação da imagem produzida com o espaço referente. Estes em muitos momentos não conseguem diferenciar a imagem de seu referente, quando convertem a imagem na própria realidade:

Por que olhando a imagem a gente vê ângulos bom e os ruin os falhos e os detalhes e também (podeiros) corregir o erro dependendo do caso a imagem pode ter outro significado das imagens. E. D., (15 anos).

Por que eu olho para o espaço como se eu estivesse olhando para qualquer coisa e olhar para o espaço melhora minha identidade por que tem várias imagens no espaço diferentes que eu nem ninguém tem condição de olhar com um pouco de atenção e ver que o plano é aquele eu vejo e outra pessoa vê. D. A., (15 anos). 
O olhar sempre modificará por cada imagem. Cada imagem que você observa você vai ter um olhar diferenciado tipo, numa rua você várias imagens tristes você vai ter um olhar mais teve tristonho um olhar de Humildade, e quando você vai em outra rua você vê coisas mais vivas pessoas alegres imagens lindas você passa a ter um outro olhar. (Diferenciado) (...)você observa melhor as imagens como se você conversa-se com elas ao você olhar para uma imagem observar corretamente com atenção analisar bem, sempre você encontrará algo diferente, você em um espaço (local) você identifica cada imagem mais não aprende a olhar de uma maneira que você possa se identificar com ela, você aprende com a imagem. R., (15 anos).

O meu olhar ficou mais "observativo", pois tudo o que vemos é imagem é fotografia, mas sempre passamos pelos locais e não percebemos a quantidade de imagem que nos rodeiam. L., (15 anos).

Antes de não saber os mistérios de fotografar eu olhava meu espaço de um jeito que todos não prestava a atenção nos detalhes nos ângulos e etc. agora já consigo focar o que é fotografia quase tudo que a gente vê é uma fotografia. L. E., (14 anos) ${ }^{7}$.

A experiência de 2010 revelou além de um olhar para a paisagem física, uma imersão na paisagem humana que compõe a região. A presença de alunos caminhando pelas manhãs do bairro, interferiu na rotina dos moradores. Possibilitou com que os alunos reorientassem seus próprios olhares sobre o espaço e os personagens que o compõe.

A construção do tema sobre o espaço que envolve o colégio se complementava em seus personagens, no cotidiano. Nas ações diárias, do varrer a frente da residência, à espera do ônibus, o transeunte e o trabalhador local.

\footnotetext{
7 Sobre a grafia dos relatórios, optou-se por manter o formato original. Estas falas dos alunos refletiam os estágios de aprendizagem da cada aluno, a bagagem educacional e consequentemente conceitual que trazem consigo em sua formação cultural dentro e fora do ambiente escolar. O emprego do termo imagem revelou nesta experiência certa dificuldade de se criar um distanciamento abstrato do espaço concreto. O que eles chamavam de imagem era o próprio referente visual. $\mathrm{E}$ isso se repetiu nos relatórios das outras experiências educacionais. Conceitualmente muitos alunos não conseguiram separar imagem de referente, outros converteram o referente em imagem em um exercício instintivo de distanciamento e naturalização da paisagem, o que em muitos momentos revelou a neutralidade do lugar cotidiano, quando os estímulos visuais se materializava na imagem e não enquanto estímulos, algo distante, motivada por uma proposta externa ao grupo.
} 


\section{EDUCAÇÃO, ARTE'S E INCLUSÃO}

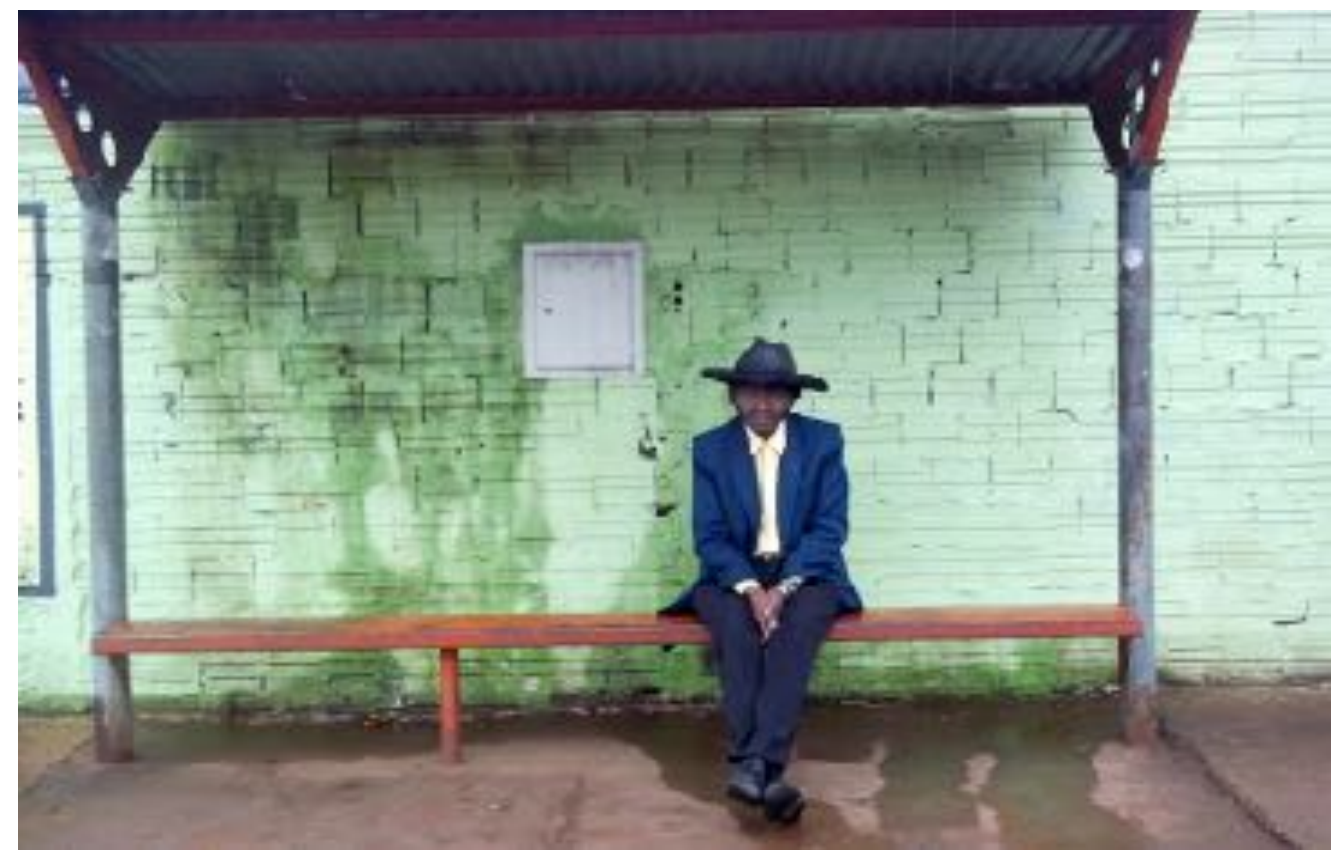

Imagem 8

K. P. (15 anos), Senhor de chapéu no ponto de ônibus, Avenida Saul Elkind.

\section{Um novo olhar sobre o espaço: reflexões pós-produção}

Os debates e relatórios de pós-produção serviram em todas as experiências para 0 aprofundamento do tema presentificado nas imagens fotográficas ${ }^{8}$. Possibilitando, que os alunos compreendessem que as fotografias são representações, todavia dotadas de significações diversas e é na ação crítica posterior a produção que estas afloraram, o que legitimou e tornou extremamente necessário neste processo de construção de um raciocínio visual a ação de fruição da produção. Não como um ato isolado, mas como uma proposta coletiva que viabiliza a troca de conhecimentos,

\footnotetext{
${ }^{8}$ As narrativas surgiram de atividades de pós-produção, direcionadas ao próprio trabalho desenvolvido, os cinco questionamentos confrontavam o aluno e seus estágios de leitura do espaço:

- $\quad$ Sobre o estudo fotográfico que desenvolveu, aponte qual o tema que procurou direcionar no conjunto de fotografias que realizou.

- $\quad$ Ao registrar a paisagem de seu bairro, alguns aspectos se colocaram em relevo, aponte-os.

- $\quad$ Antes de iniciar esse estudo fotográfico qual leitura fazia de seu bairro?

- Qual a contribuição deste trabalho para melhorar o seu conhecimento do espaço em que vive?

- Reflita sobre a afirmação: "fotografar é olhar com uma lupa a minúcia das coisas".
} 
comentários que tornassem presentes os problemas plásticos que se manifestavam em cada trabalho.

Porém é evidente o choque perceptivo que se estabelece nestes jovens quando retirados de seu lugar seguro, quando colocados a se confrontarem com uma realidade até então imperceptível, distante do espaço escolar e de suas respectivas áreas de segurança identitárias.

O ponto em comum nos relatos dos três momentos desta experiência educacional consistia em que todo o espaço que os envolvia era visto por muitos como um espaço de trânsito, quando convertido em corpo de exploração estética permitia neste processo educacional que uma outra instância de significações se presentifique nas observações dos alunos, aflorando indagações sobre poluição, violência, descaso do Poder Público etc.

Quando estimulados a falarem sobre as percepções que tinham construído do espaço em suas pós-produções, seja oralmente ou de forma escrita, os alunos acresciam a suas descobertas pessoais, indagações que transcendiam a composição estética das imagens. O modo como compreendiam o espaço, e suas descobertas pessoais, em muitas falas a dimensão impessoal do espaço, foi tomada por leituras detalhadas, descritivas sobre o lugar e os espaços ocupados pelos indivíduos.

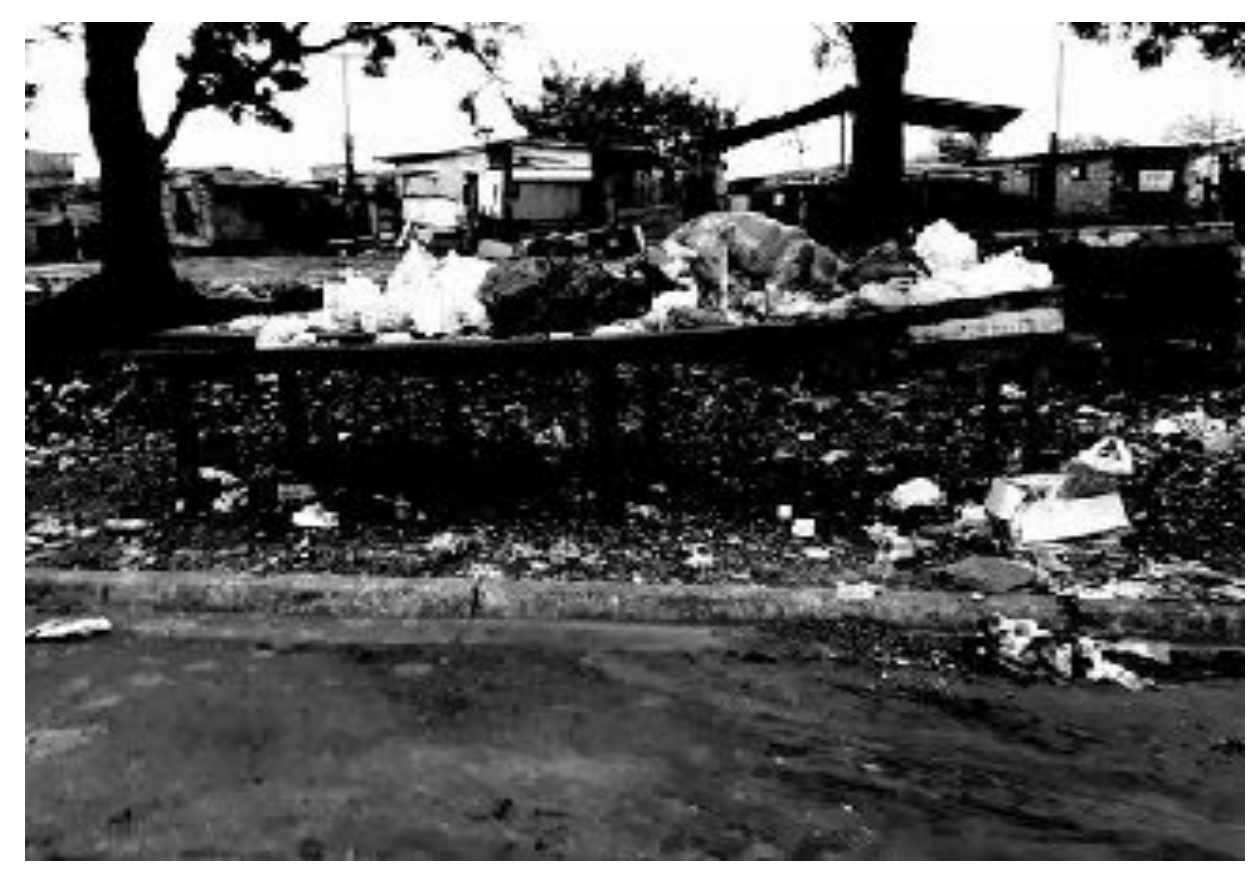


Como estratégia de construção do debate, o primeiro questionamento remetia à como os alunos percebiam esse espaço. A partir disso objetivava-se compreender a relação do indivíduo com o meio. Muitos apontavam como um espaço normal ${ }^{9}$. O que levou a um segundo questionamento sobre essa representação: "o que é normal?". Relataram uma realidade de bairros violentos, precários e com um grave problema socioambiental (um lixão em seu fundo de vale) como estudantes moradores deste e das imediações.

Nas falas e relatos escritos de alguns alunos a palavra normal refletia a naturalização daquilo que não é percebido, ou é visto por olhares externos, pois esta palavra sempre precedia falas que se remetiam a: "passei a reparar os detalhes", e posteriormente, retornam a naturalização do espaço: "há beleza no lixão"; este retorno a naturalização do espaço, nas falas de alguns alunos vinha acompanhado de um posicionamento crítico.

O cidadão aqui se manifestava em uma leitura que transcendia o estética, nas falas que situavam os problemas do bairro, o lixão por exemplo, que mesmo naturalizado por alguns, estetizado por outros, não deixava de seu um estigma, e um problema socioambiental para todos.

9 Em sua maioria, essa normalidade foi apontada nas falas e relatos das turmas de 2010. As turmas de 2017, se incomodavam muito com o descaso com o espaço, enquanto que os alunos de 2018, deixavam transparecer certo incômodo com a violência e a poluição crescente do espaço. 


\section{EDUCACÃO,}

ARTES E INCLUSÃO

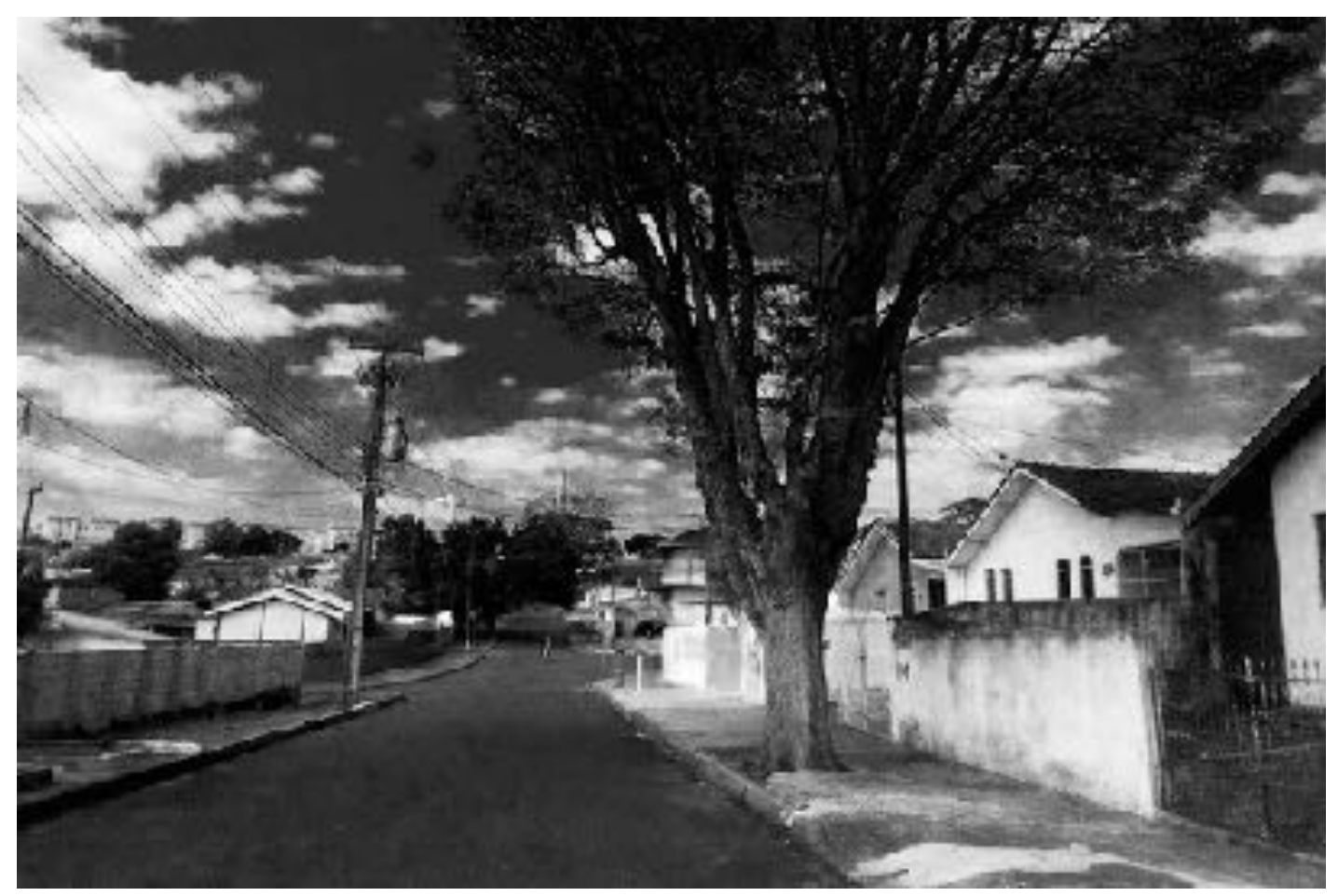

Imagem 10

A.

R. (16 anos) Conjunto Parigot de Souza II, 2017.

Adriana Rodrigues.

Em outros momentos nos relatos, destacava-se a ideia de espaço como algo heterogêneo, "espaços", o que refletia a consciência de um espaço fragmentado, múltiplo, mas ao mesmo tempo, não tornava o lugar um ponto de referência entre os jovens e o bairro, os espaços como algo distante.

Quando questionados sobre a identidade em relação ao mesmo, em sua maioria, demonstram a compreensão de que o espaço é coletivo e mantem-se externo as suas individualidades, porém, quando remeteram-se a ação de criação fotográfica, os reconheciam como familiar, internalizado, convertido em uma imagem mental, fruto de uma escolha, de um plano de observação, como podemos ver nos relatos dos alunos envolvidos na experiência em 2017: 
"A minha expectativa não era só mostrar as coisas ruins do meu bairro e sim as boas, procurei usar a iluminação, o espaço, as cores, o 'objeto' que chamasse mais a atenção". P.B - (16 anos)

"As fotos ficaram de temas diferentes mas que se complementam como por exemplo a imagem do animal na foto da ideia da vida do campo se mistura como o da cidade. Ou a do lixo encostado ao muro que nem percebemos mais como se tivesse virado uma decoração da paisagem desde o princípio. Ou seja, quis direcionar as fotos do que para nos é despercebido e considerado algo natural da paisagem, sendo que não é, tipo: o animal na rua, o lixo no muro, o caco de vidro barato no muro, pneus recicláveis como decoração, arte feita no muro, luz colorida sobre a porta de vidro da igreja católica, e uma estradinha de barro paredada com cerca de madeira mal feita". M. A. - (17 anos).

"O meu bairro é muito bom de se morar, faz 16 anos que ele é a mesma coisa a respeito de tranquilidade, mas minhas fotografias quis mesmo capturar as decadências dele, as ruas que os políticos falam que vão arrumar e cada vez está pior, as pessoas que não se preocupam com a aparência de suas casas, os lixos que jogam sem se preocupar com o prejuízo depois". L.S. - (16 anos).

“O tema em que eu escolhi foi não 'tirar' a pobreza mas faze-la em algo belo, era ver o meu cotidiano de outra forma que não via através da câmera. (...) Um dos principais aspectos em que foram relevantes foi a interferência dos animais nos entulhos, as crianças tão alegres e brincalhonas e trabalhadores exaustos e muito abatidos, transformando minha fotografia em algo tão poético" A. P. de S. - (17 anos).

"Eu fotografei o lazer das pessoas, procurei fotografar as crianças soltando pipa. Estava na época de pipa, já acabou. (...) Nas imagens que fotografei, alguns relevos que haviam eram entulhos no Nossa Senhora Aparecida, meu Amigo soltando pipa e o cachorro comendo lixo". J A. - (17anos).

"Queria mostrar a realidade de um bairro que muitas pessoas conhecem mas poucos sabem a origem, eu queria fotografar lugares onde pra alguns não tem utilidade em nada mais pros Sinceramente, meu bairro é lindo" R. V. B. (17 anos). 
O olhar exploratório é o que movimenta essa proposta de ensino, incentivando os alunos a procurarem as minucias no cotidiano, o transformamos em uma grande fonte de informações, capaz de construir significados e referenciais para a produção artística que se pretende questionadora do cotidiano. Com isso os alunos foram instigados a estabelecerem novas indagações sobre o meio. Sobre a paisagem que the envolve, e possibilitando explorar neste contato, suas formas, cores, sons, cheiros e texturas.

\section{Considerações finais}

As fotografias são representações, todavia dotadas de significações diversas e é na ação crítica posterior a produção que estas afloram, o que legitima e torna extremamente necessário neste processo de construção de um raciocínio visual a ação de fruição da produção. Não como um ato isolado, mas como uma proposta coletiva que viabiliza a troca de conhecimentos, comentários que tornem presentes os problemas plásticos que se manifestam em cada trabalho.

É evidente o choque perceptivo que se estabelece nestes jovens quando retirados de seu lugar seguro, quando colocados a se confrontarem com uma realidade até então imperceptível, distante do espaço da escola e de suas respectivas áreas de segurança identitárias. O bairro, visto por muitos como um espaço de trânsito, quando convertido em corpo de exploração estética permite neste processo educacional que uma outra instância de significações se presentifique nas observações dos alunos. São três momentos de vivências. Logo três experiências fotográficas que revelam na distância destes oito anos, as transformações físicas no espaço, assim como as transformações na geração de olhas que se depositam sobre a paisagem explorada.

São dezenas de intencionalidades que se manifestam por aparelhos celulares. Registros dos conjuntos habitacionais, do assentamento, dos bairros do entorno. 
Surgem nas narrativas a tentativa de se construir identidades, remetendo-se ao espaço como uma área de pertencimento ${ }^{10}$.

\section{REFERÊNCIAS}

ARANHA, Carmen S. G. Exercícios do Olhar. $1^{\text {a }}$ ed. São Paulo: Unesp; Rio de Janeiro: FUNARTE, 2008.

DUBOIS, Philippe. $\mathbf{O}$ ato fotográfico. Campinas, Papirus Editora, 2009.

BERGER, Peter \& LUCKMANN, Thomas. A Construção Social da Realidade. Petrópolis, Vozes, 1985.

CANTON, Kátia. Espaço e Lugar- temas da Arte Contemporânea. São Paulo, Martins Fontes, 2009.

FERRAZ, Maria Heloisa C. de T. e FUSARI, Maria F. de Rezende. Arte na Educação Escolar. São Paulo, Cortez Editora, 2010.

JOLY, Martine. Introdução à análise da imagem. Campinas, Papirus Editora, 2008.

PARANÁ. Secretaria de Estado da Educação do. Diretrizes Curriculares de Arte para a Educação Básica. Departamento de Educação Básica. Curitiba, 2008.

SONTAG, Susan. Sobre fotografia. $5^{\text {a }}$ ed. São Paulo, Cia das Letras, 2004.

Recebido em 11 de janeiro de 2019

Aprovado em 27 de março de 2020

10 Sobre essas experiências fotográficas, parte dos ensaios fotográficos desenvolvidos pelos alunos estão disponibilizados neste link: https: //andrecamargolopes1976.blogspot.com/2018/12/projeto-meubairro-ensaios2017.html 